\section{NATIONAL PHYSICAL LABORATORY}

\section{Open Days Divided}

THE National Physical Laboratory at Teddington has found that the way to organize its annual open days is to show only a third of the laboratory each year. This way, the advances made by each of the three groups into which the laboratory has been divided is measured on a three-year time scale, often more flattering than an annual inspection. This year, it is the turn of the materials group, which will be judged by whether it is fulfilling its aim of providing the technical background to industrial innovation. This year's open days will be on May 14 and 15 .

Like much of what the NPL does, the work of the materials group is necessary and worthwhile but only rarely stirring. Its functions include the provision of chemical standards, the applications of materials (chiefly iron alloys and high temperature materials), the investigation of the relation between microstructure and the physical properties of inorganic materials, and the properties of polymers of high molecular weight (molecular science).

The way in which a technique for the study of surfaces has been applied to biology, only a footnote to the work of the materials group, has turned out to be one of its successes. In collaboration with the Royal Postgraduate Medical School, Hammersmith, the laboratory is using radio frequency sputtering equipment to etch human red blood cells (S. M. Lewis, J. S. Osborn and P. R. Stuart, Nature, 220, 614; 1968). Under the scanning electron microscope, the etching gives new information on the structure of the cells.

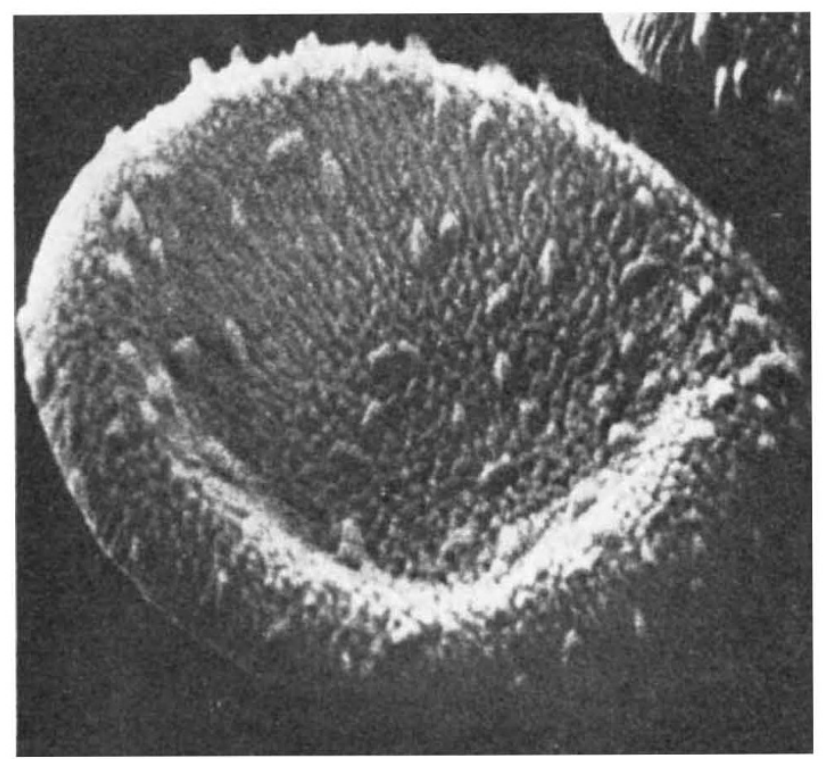

An abnormal human red blood cell after etching $(\times 10,000)$. The cell has the haemoglobin abnormality Hb-Köln, and shows haemoglobin aggregates known as Heinz bodies.

This seems to be the only way of looking beneath the superficial layers of the cell membrane. Just now, the intention is to see to what extent the topography of the etched cell reflects the structure of the membrane, and to extend to other biological materials what is proving to be a versatile technique which is attracting a deal of attention.

On the carbon fibres front, an ultrasonic method for measuring the elastic constants of reinforced composites is being developed. The problem seems to be to measure rapidly the properties of materials designed to have great strength in only selected directions, and the method is to propagate an ultrasonic pulse at an angle through the specimen. Both longitudinal and shear waves can be transmitted, and the constants are calculated from measurements of the wave velocities in several directions.

\section{CONFERENCES \\ Country life}

THE Gordon Conferences have been a familiar feature of the American academic scene for many years now: they are week-long summer meetings devoted to some fairly general research topic_-"catalysis" or "membranes", for example-with attendance limitcd to a hundred or so active research workers. They seem to be an effective way of generating and communicating ideas, and they have certainly flourished numerically, from a single meeting in 1931 to about 60 meetings each year now.

Britain's introduction to this style of conference will come in September when the Biochemical Society holds its first Harden Conference at Wye College, Ashford, Kent. The Biochemical Society has chosen a mammoth subject, "The Structure and Biological Role of Proteins", and topics will range from enzyme kinetics to antibody structure, from metabolic control to peptide synthesis.

The essence of such conferences is that productive research scientists at all levels of attainment should live cheek by jowl for a few days in pastoral and relaxed surroundings. Some scientists of proven stature are paid to come, while the rest pay. Grants from the Royal Society, the Wellcome Trust and the Biological Council have, however, made it possible for the Biochemical Society to charge its paying guests no more than a fully inclusive $£ 30$ for the week-long meeting. A distinguished roster of British speakers has been booked, and they will be joined by such luminaries from overseas as C. B. Anfinsen from Bethesda, R. B. Merrifield, fresh from making ribonuclease, and Benno Hess from Dortmund. Professor D. C. Phillips will act as chairman for the week.

A hundred paying applicants can be accepted, but the Biochemical Society is waiting for the applications to start coming in before it decides just what criteria to use in making its selection. It is also waiting to see how the conference turns out before promising a repeat performance next year. In the United States, each Gordon Conference behaves something like a plastid, passing from year to year in autonomous descent. The final act of a Gordon Conference each year is to elect a chairman to supervise its own re-emergence in the following year. But the Biochemical Society is not yet committing itself to this mode of propagation.

It will be interesting to see if the Harden Conference -its name commemorates a pioneer investigator of fermentation - can carve a niche for itself in the teeming world of scientific gatherings. New meetings face stiff competition these days. They have to contend with gatherings like those at Cold Spring Harbor in terms of prestige, and all those summer schools on Greek islands or half way up Swiss alps in terms of hedonism. 